\title{
THE MORPHOLOGICAL EFFECTS OF SURGES OF THE DONJEK GLACIER, ST ELIAS MOUNTAINS, YUKON TERRITORY, CANADA
}

\author{
By P. G. Johnson \\ (Department of Geography, Faculty of Arts, University of Ottawa, Ottawa 2, Ontario, \\ Canada)
}

\begin{abstract}
The present surge of the Donjek Glacier on the north-east side of the St Elias Mountains, first noticed in 1969 , is producing a number of morphological effects adjacent to the glacier in the terminus area. Although the effects of the surge are minimized by the lobate form of the glacier terminus, several types of push structure, erosional forms and certain drainage changes are being produced. These forms are similar to older forms close to, or on, the Neoglacial maximum moraine. It is considered that the similarities suggest that surges may have occurred throughout most of the Neoglacial period.
\end{abstract}

RÉsumÉ. Les effets morphologiques des crues rapides du Donjek Glacier, St Elias Mountains, Yukon Territory, Canada. La crue rapide actuelle du sur le versant nord-est de St Elias Mountains, rapportée une première fois en r 969 est en train de produire nombre d'effets morphologiques en bordure du glacier dans le zone terminale. Bien que les effets de la crue soient minimisés par la forme en lobe de la langue glaciaire, il s'est produit plusieurs formes de structures de poussées, des formes d'érosion et certains changements dans le réseau de drainage. Ces formes sont semblables à des formes plus vieilles, coïncidentes ou toutes proches de l'époque de la moraine maximum du Néoglaciaire. On considère que ces ressemblances suggèrent que de telles crues rapides peuvent s'être produites pendant la plus grande partie de la période Néoglaciaire.

Zusammenfassung. Morphologische Auswirkungen schneller Vorstösse des Donjek Glacier, St Elias Mountains, Yukon Territory, Kanada. Der augenblickliche schnelle Vorstoss des Donjek Glaciers an der Nord-Ost-Seite der St Elias Mountains - erstmals 1969 festgestellt - verursacht eine Reihe morphologischer Erscheinungen im Zungengebiet des Gletschers. Wenn auch die Auswirkungen des schnellen Vorstosses durch die Lobusform des Gletscherendes gemindert werden, werden doch mehrere Arten von Stauchstrukturen, Erosionsformen und gewisse Veränderungen im Abflusssystem hervorgerufen. Diese Formen sind älteren Formen nahe an oder auf der Moräne des neoglazialen Maximums ähnlich. Aufgrund dieser Ähnlichkeiten wird angenommen, dass schnelle Vorstösse auch während des Neoglazials immer wieder aufgetreten sind.

\section{INTRODUCTION}

The glaciers which flow from the icefield of the St Elias Mountains in the south-west of Yukon Territory are probably the best known surging glaciers. Many of the glaciers in the area are known to have surged or show the indicative morphological characteristics (Rutter, I969; Meier and Post, I969). The Donjek Glacier, one of the largest valley glaciers in the St Elias Mountains, (Denton and Stuiver 1966, 1967), is one for which there is photographic evidence of recent fluctuations of the terminus (Photographs by W. A. Wood and A. Post). In 1969 aerial photographic reconnaissance by A. Post (personal communication) indicated that the glacier was starting a period of surge.

The Donjek Glacier lies on the north-east side of the St Elias Mountains and stretches for about $55 \mathrm{~km}$ from the icefield to its terminus. The glacier is a typical valley glacier and it terminates at the point where the Donjek Glacier valley joins the Donjek River valley (Fig. I). This situation at the terminus has produced a lobate terminal form to the glacier, where the ice has spread out into the wide valley floor of the Donjek River valley, which has meant that some of the morphological effects of the surge are reduced.

\section{EFFECTS OF THE I969 SURGE}

Apart from the terminal area, the effects of the rg69 surge have been similar to those observed elsewhere (Meier and Post, 1969). Dislocations at the junction of the icefield with the ice and snow cover of the surrounding mountains indicate a diminishing in height of the ice in the accumulation area. Below the firn line there is considerable disruption of the glacier surface with large open crevasse systems and ice pinnacles (Fig. 2). Along the margins of the 

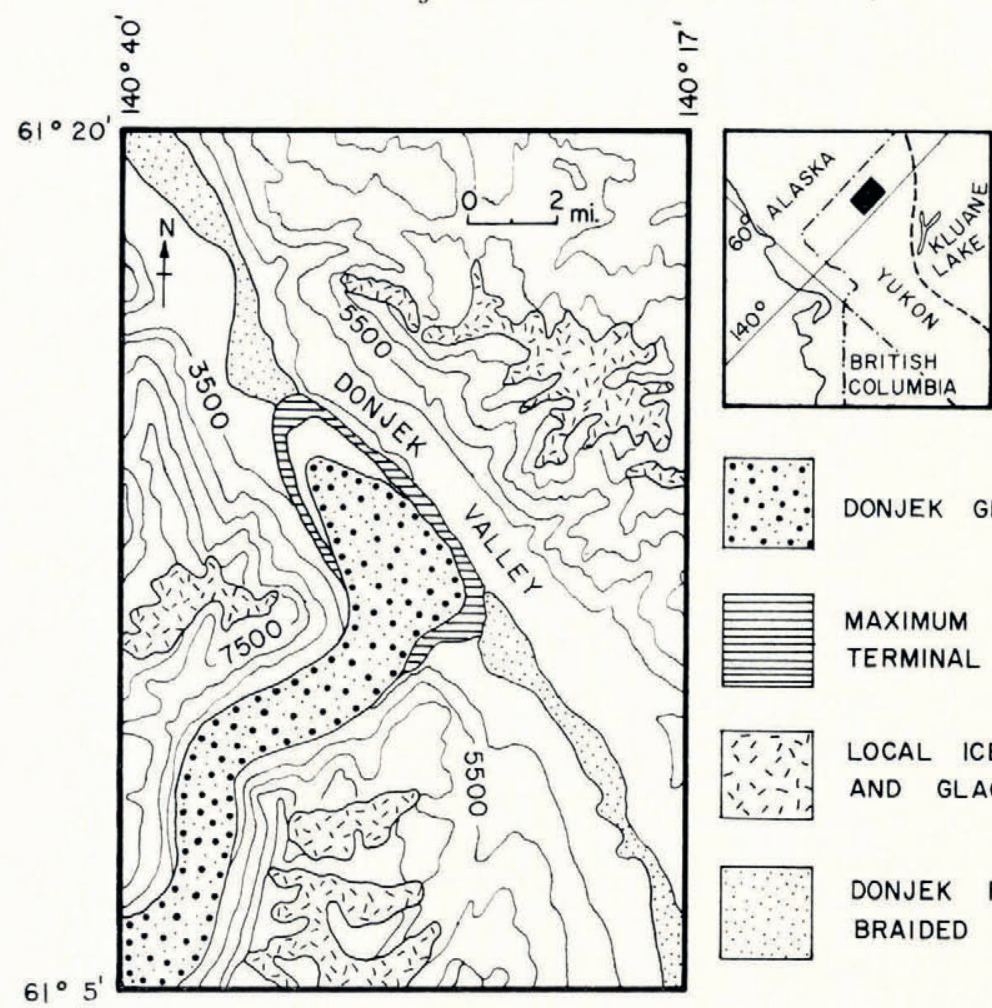

LOCATION OF THE DONJEK GLACIER S.W. YUKON TERRITORY

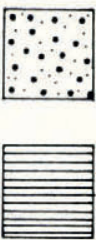
DONJEK GLACIER

MAXIMUM NEOGLACIAL TERMINAL MORAINE

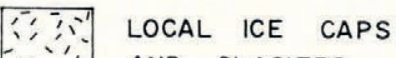

ㄴ, AND GLACIERS

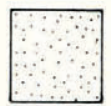

DONJEK RIVER

BRAIDED COURSE

Fig. I. The terminus of the Donjek Glacier.

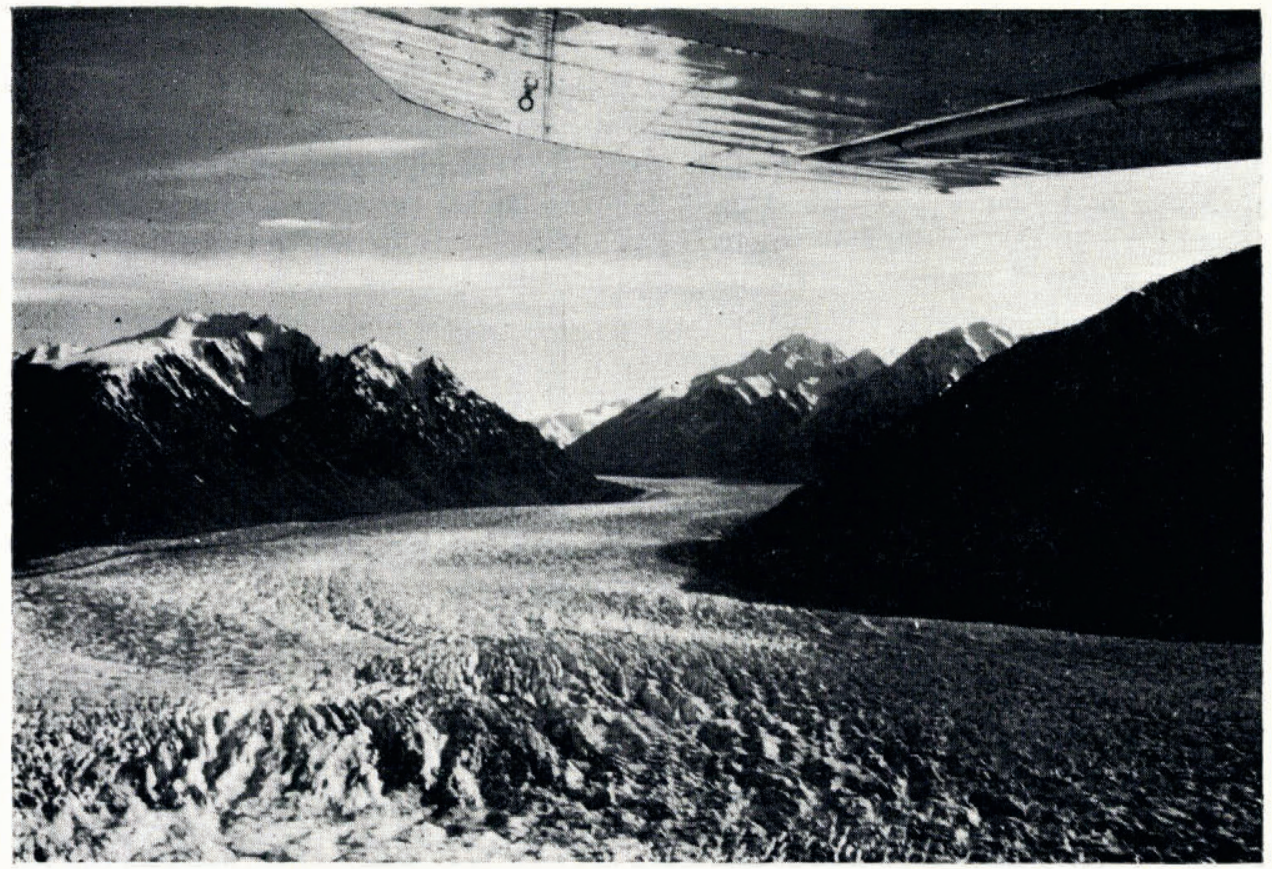

Fig. 2. The surface of the surging Donjek Glacier. 
glacier a number of the small tributary glaciers have been truncated by the unusually rapid movement of the main glacier. In addition a record of former surges exists in the margins of the glacier in the form of isolated tongues of tributary glaciers which have been cut off and moved down glacier by successive periods of surge (Fig. 3).

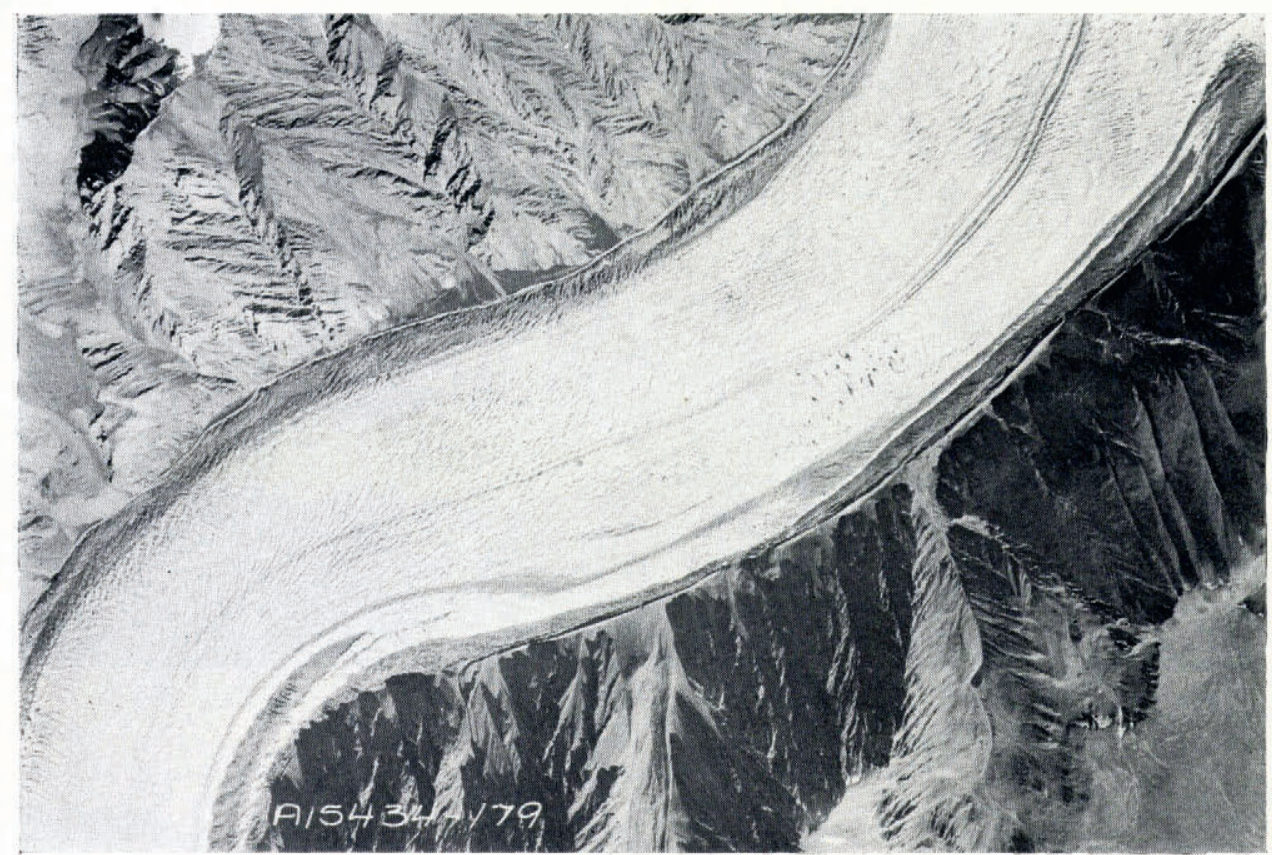

Fig. 3. Truncated termini of a tributary glacier on the south side of the Donjek Glacier (Photograph from aerial photograph A I 5434-I79, reproduced by permission of the National Air Photo Library, Surveys and Mapping Branch, Department of Energy, Mines and Resources, Ottawa, Canada).

Although the surge has had the effect of reactivating the terminus of the glacier, producing an almost vertical, unstable, ice face of up to $30 \mathrm{~m}$ in height (Fig. 4), there has been little readvance of the terminal position. This is due, most probably, to the dissipation of the movement in the lobate form of the glacier terminus (Fig. 5). The present surge has resulted in a movement of less than a $500 \mathrm{~m}$ down the river valley and the movement across the valley has been less than $100 \mathrm{~m}$. This movement may be compared to that of earlier surges in 1935 and 1962 which produced maximum advances down the river valley of about a kilometre. The rather limited movement toward the valley wall is problematical. It does not appear to be due to the physical restriction of the valley side since the Donjek River has maintained its course between the glacier and the valley wall.

Below the vertical face of the active glacier terminus there is an area of stagnant ice with a low angle of slope (Fig. 4). This stagnant ice is separated from the active ice by a distinct structural break. It is apparent, from a study of aerial photographs of the glacier, that this ice is the remains of the pre-surge terminus which is now being pushed by the reactivated glacier. The stagnant ice is in some areas rapidly ablating due to a thin cover of silts and clays and in other areas is being covered with outwash debris.

The recent movement of the terminus has resulted in the formation of a number of push structures. Field observations showed that the Neoglacial moraine is extensively ice cored. The push of the active ice into the older moraine has resulted in the shear of the stagnant 


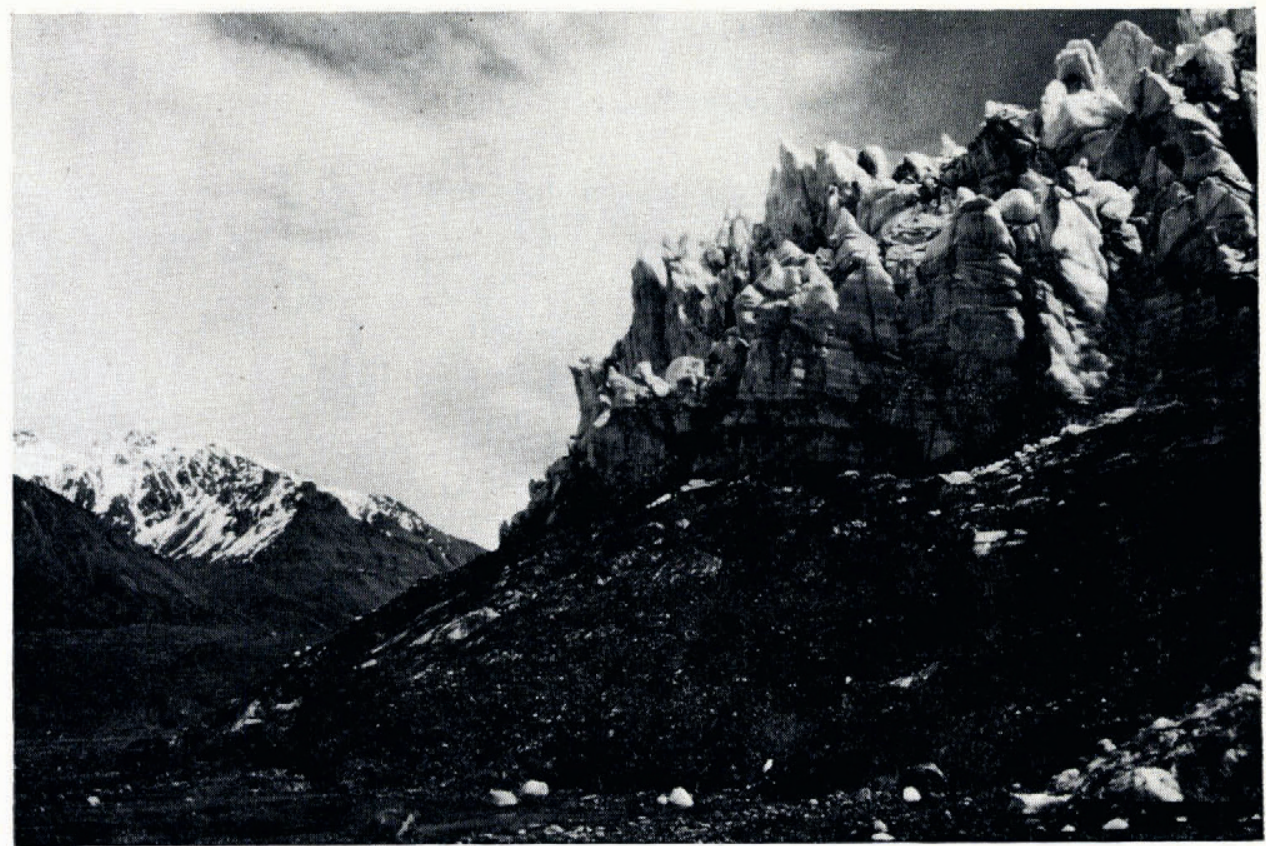

Fig. 4. Ablation-covered wedge of stagnant ice being pushed in front of the surging Donjek Glacier.

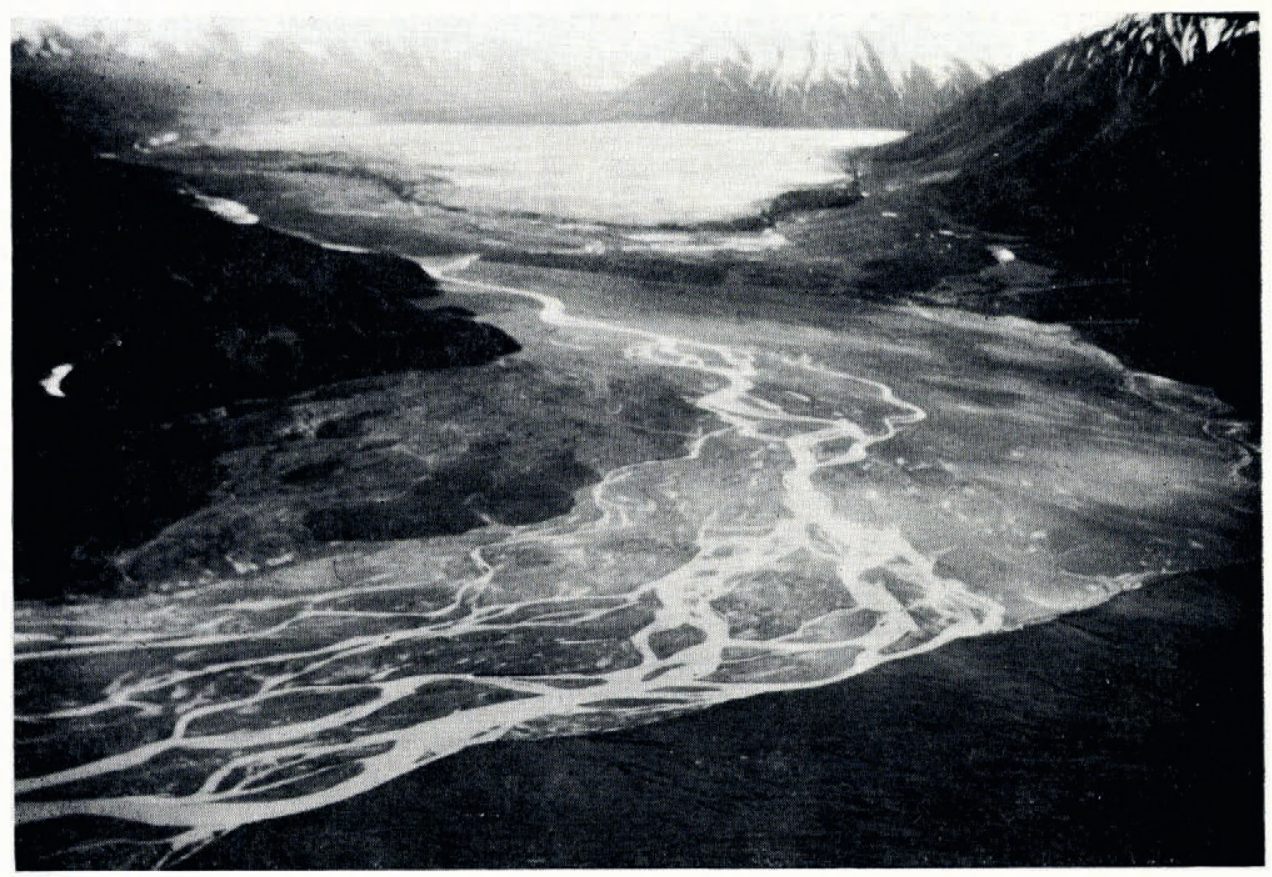

Fig. 5. The terminus of the Donjek Glacier showing the lobate form of the terminal area. 
glacier ice core towards the surface, and in places this ice has been exposed (Fig. 6). Similar ice-cored moraines have been described in Scandinavia by Østrem (I959, I962, I964). Theoretically the rate of erosion of the exposed face of till and ice would be very rapid due to the melting of the ice and the slumping and subsequent flow of the overlying till. In the early summer of 1970 the average rate of retreat on the Donjek moraine exposure was $0.6 \mathrm{~m}$ per week. The push of the active ice across the outwash area adjacent to the terminus in a downriver valley direction has produced two moraine forms which are up to $3 \mathrm{~m}$ in height. One form is ice cored and is being produced by the shear of stagnant ice from beneath the outwash by the movement of the glacier and the second is being produced by the deformation of the till and outwash in a saturated condition immediately adjacent to the glacier (Fig. 7).

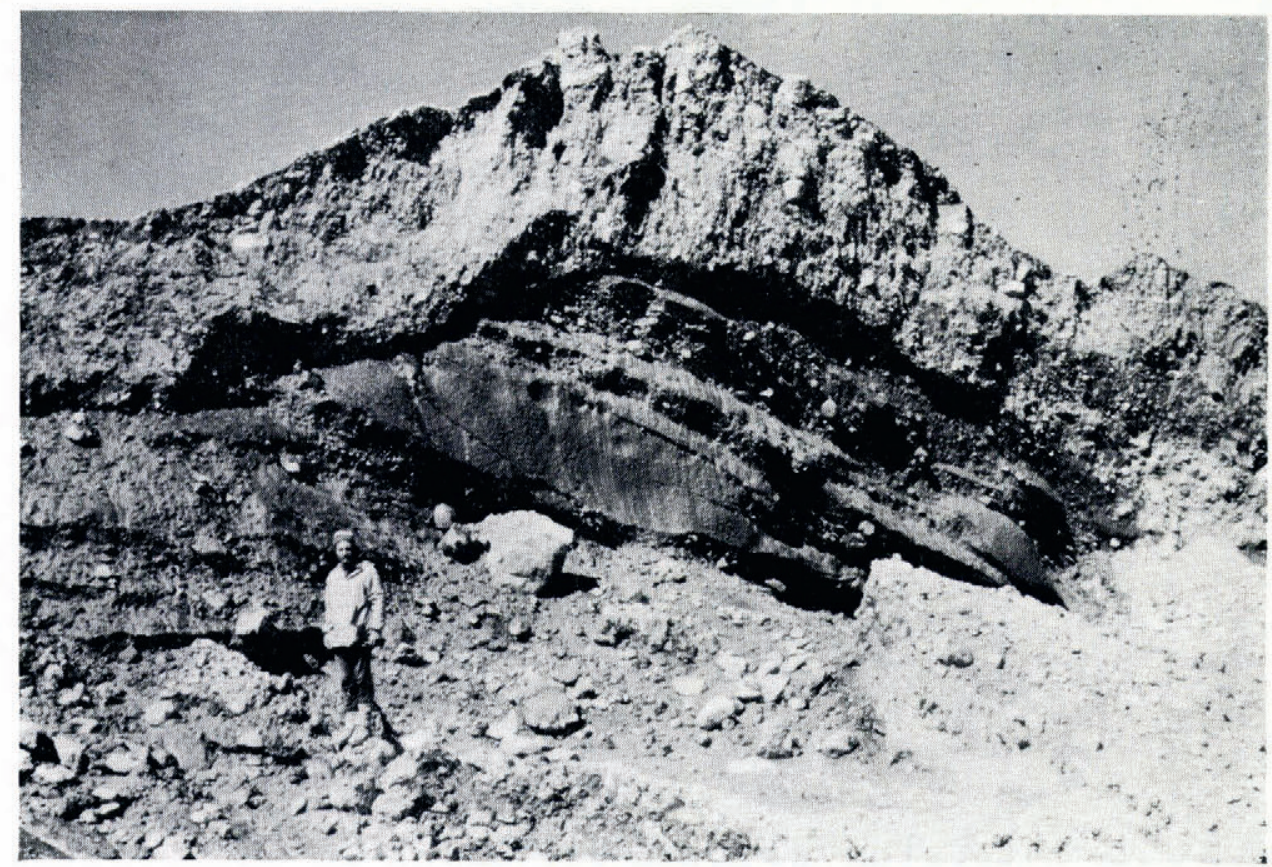

Fig. 6. Ice core to the main Neoglacial moraine.

The slight re-advance of the glacier terminus during the present surge is eroding a large area of crevasse fillings, which had been deposited during the down-wasting of the ice from the maximum position of $\mathrm{r} 96 \mathrm{r}$. Some minor moraine ridges which had been deposited during the last thirty years are also being degraded. On the south-west side of the river valley, north of the confluence of the Donjek Glacier valley with the Donjek River valley, the surge is also eroding hypsithermal alluvial fans built out from the valley side. This erosion has rejuvenated the streams crossing these fans and some have incised themselves up to a depth of $45 \mathrm{~m}$ within the old fan surfaces.

\section{EFFECTS OF FORMER SURGES}

There is considerable morphological evidence which indicates that the Donjek Glacier has been affected by fluctuations of its terminus position during a considerable portion of the Neoglacial period and that the Donjek River has repeatedly changed its course. For example, in 1935, the glacier terminus was close to the position of the maximum Neoglacial moraine 


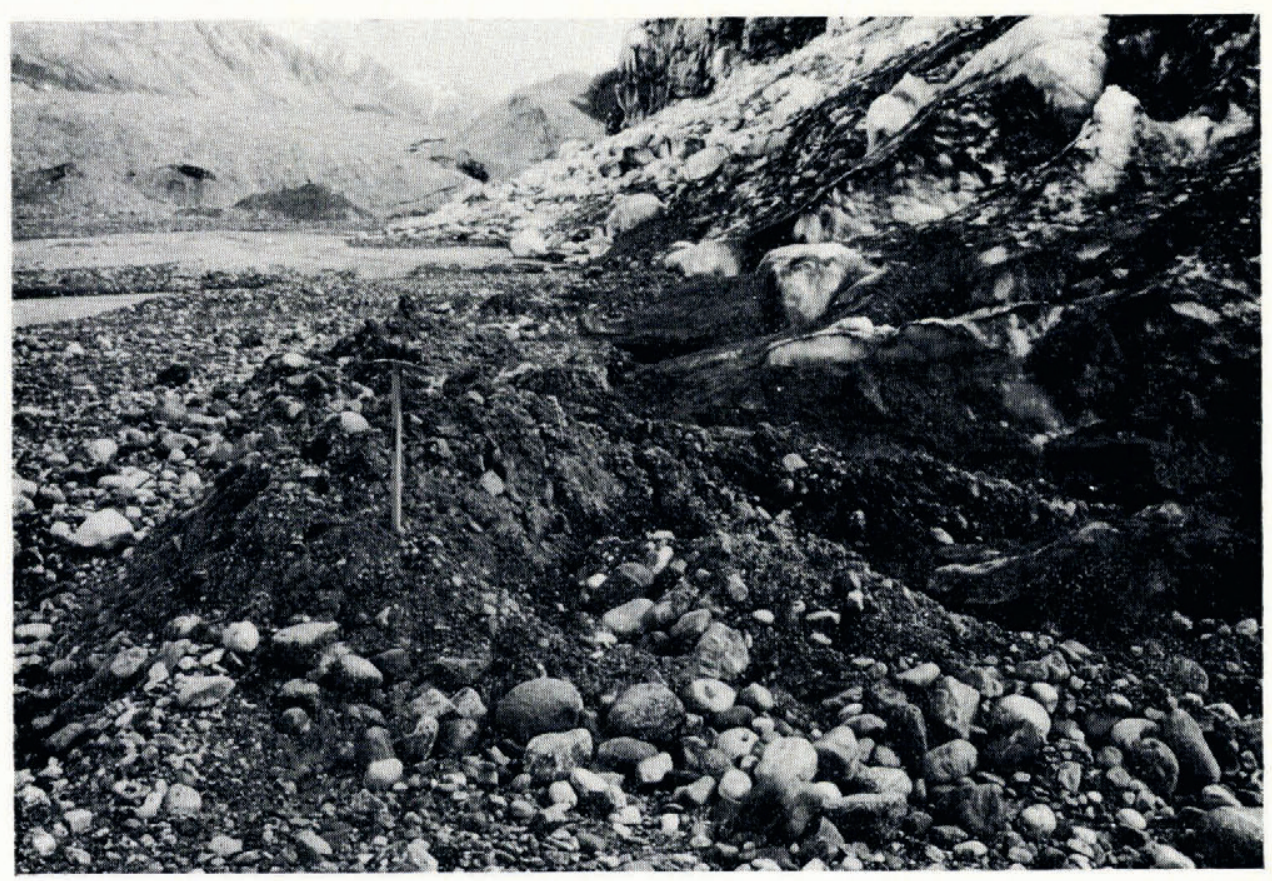

Fig. 7. Push moraine at the down-valley terminus of the Donjek Glacier.

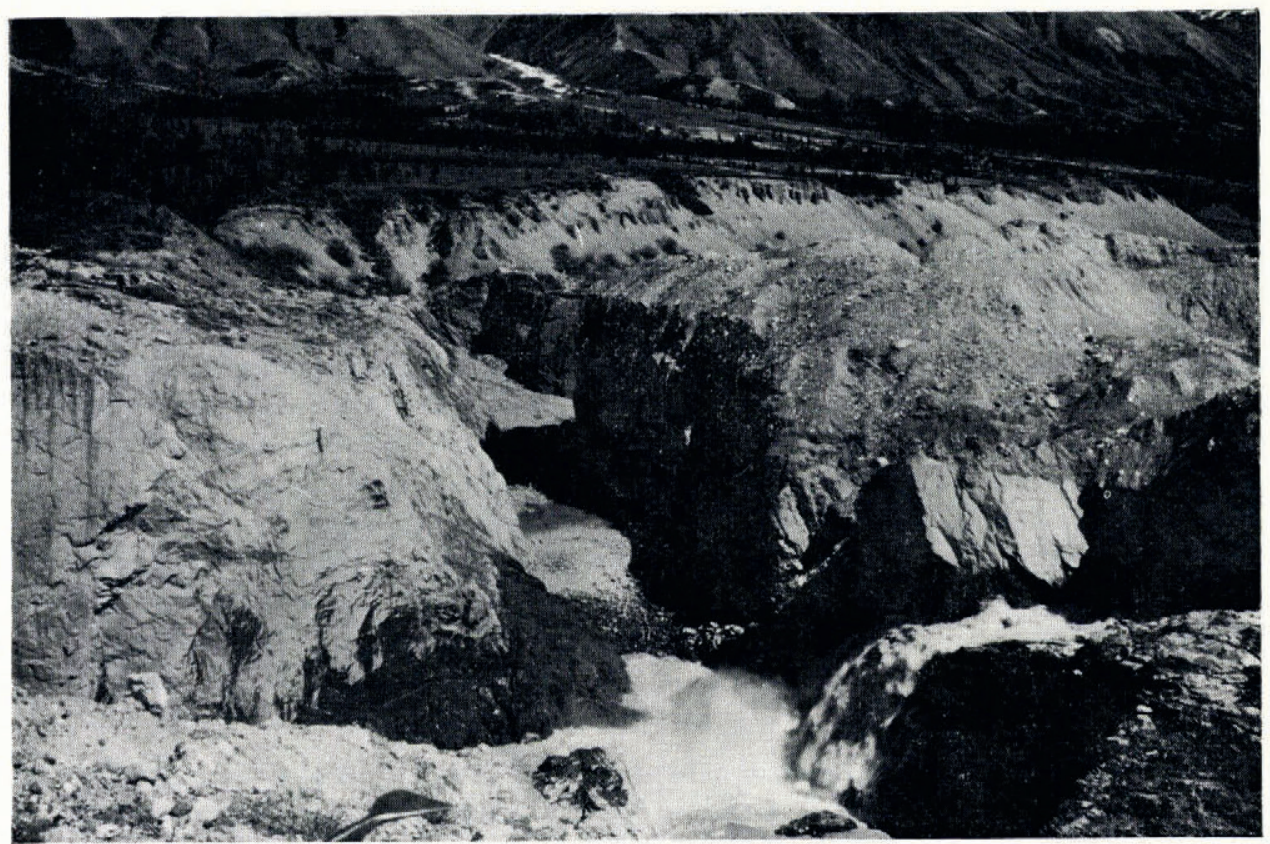

Fig. 8. The Donjek River gorges formed as a result of different periods of surge of the Donjek Glacier. 
system and the Donjek River followed its present course through the granodiorite gorges along the north-east side of the river valley. By 1956 the terminus position had retreated about $1.5 \mathrm{~km}$ and the river was flowing along the terminus of the glacier, inside the Neoglacial moraine complex, and then out, down-valley, through a large gap in the moraine. In I96r, a readvance of the glacier had again diverted the river through the grandiorite gorges. Evidence of similar changes in the course of the river prior to 1935 occurs in the pattern of dry river gorges and waterfalls (Fig. 8) along the north-east side of the valley. In view of the very recent changes in the drainage pattern related to terminus fluctuations during surges it is likely that the dry river courses may be the result of previous surges.

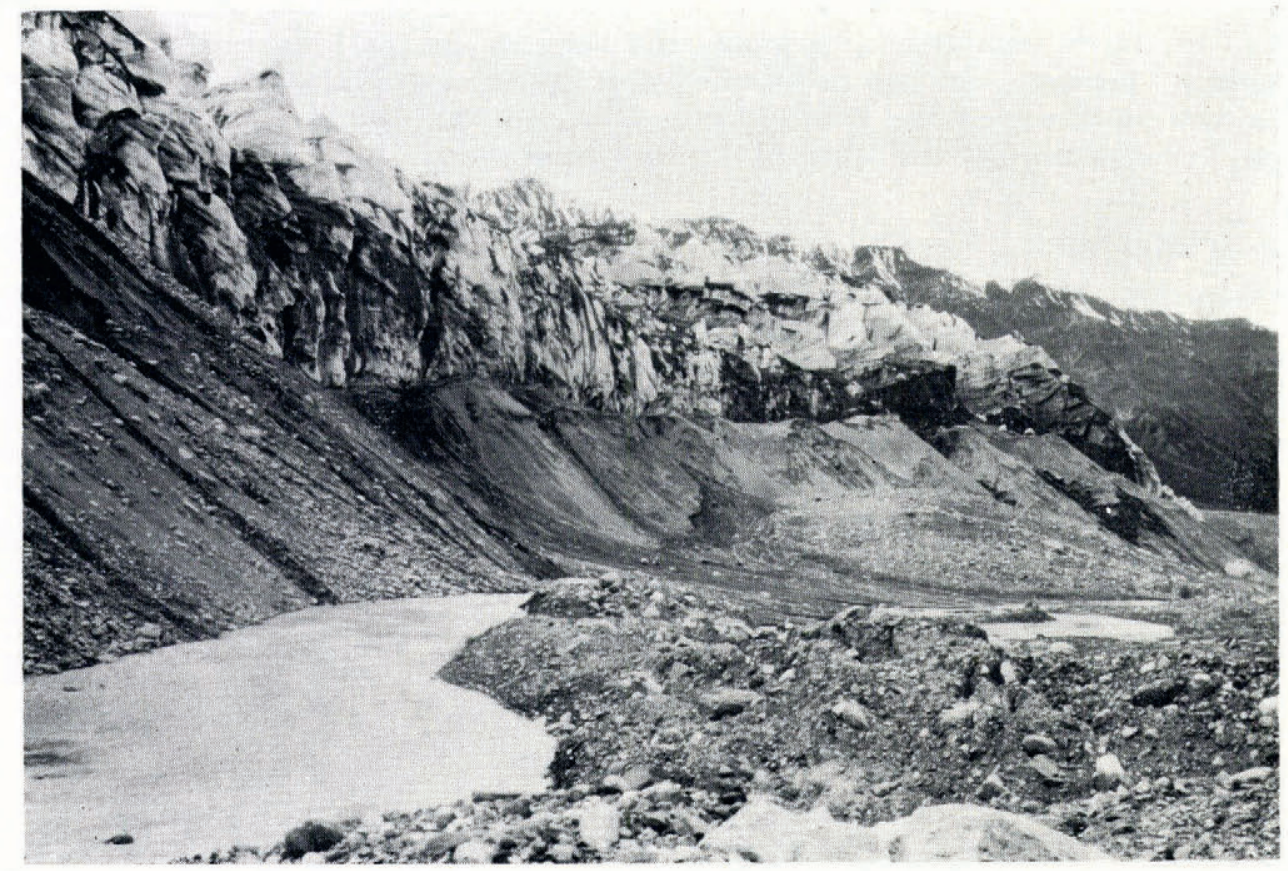

Fig. 9. Ice-cored moraine formation at the margin of the Donjek Glacier.

There is evidence for the occurrence of fluctuations of the glacier terminus on the moraines dating from the maximum of the Neoglacial (Porter and Denton 1967, Denton and Porter 1970). Some of the minor ridges on the moraine have shear and push structures which are similar to those which are now being formed at the terminus of the glacier. These push moraines are an indication of fluctuations of the glacier terminus in the period post-dating the maximum Neoglacial position, that is post 300 B.P. (Denton and Stuiver, 1966, 1967).

One area of the Neoglacial maximum moraine, on the west side of the down-valley terminus, has been considerably eroded by mudflow activity. The apparent similarity in the pattern and structures of the mudflows in this area to those where the ice core has been exposed by recent glacier activity and the occurrence of one small ice core exposure indicates a probable genetic similarity between the two areas. Photographic analysis shows that this particular area did not exist prior to the I961 surge. (Photographs by W. A. Wood.) It is probable, therefore, that the movements in $1960-6 \mathrm{r}$ exposed the ice core in the moraine and that it has taken almost ten years for the exposure to become stabilized again. 
Conditions at the terminus of the surging glacier give some indications of the mode of formation of ice-cored moraines, and also, of their relationship to the phenomena of surging. The stagnant ice of the pre-I 969 glacier, which is being pushed by active ice, is the primary area of accumulation of ablation and outwash debris. This accumulation is localized and in places a thin cover of silts is promoting the ablation of the ice. This process appears to be producing moraines (Figs. 9 and 4) of similar form to those more remote from the glacier terminus and also similar to the Neoglacial maximum moraine.

\section{Conclusions}

Although the effects of the surge of the Donjek Glacier in the terminal area have been minimized by the lobate form, a number of push and erosion forms are being produced. The similarity between the forms being produced at present and those mapped on parts of the Neoglacial maximum moraine provide evidence which, together with the indications of changes in the Donjek River drainage pattern, suggest that the Donjek Glacier has been subject to surges since the early part of the Neoglacial period.

\section{Acknowledgements}

The author wishes to acknowledge the National Research Council of Canada, who provided the financial support for the field work, the Arctic Institute of North America, particularly $\mathrm{Mr} \mathrm{P}$. Upton and $\mathrm{Mr}$ Richard Ragle, for logistics support and $\mathrm{Mr} \mathrm{K}$. Lowndes for assistance in the field. He would also like to thank Dr R. Souchez (Université de Bruxelles) and Dr H. M. French (University of Ottawa) for comments on the manuscript and Dr W. A. Wood (Arctic Institute of North America) and Mr A. S. Post (Hydrologist with the Water Resources Division of the United States Geological Survey) for photographs of the glacier.

\section{MS. received 19 April 197 I and in revised form 26 August 197 I}

\section{REFERENCES}

Denton, G. H., and Porter, S. C. 1970. Neoglaciation. Scientific American, Vol. 222, No. 6, p. 101-09.

Denton, G. H., and Stuiver, M. 1966. Neoglacial chronology, northeastern St. Elias Mountains, Canada. American Journal of Science, Vol. 264, No. 8, p. 577-99.

Denton, G. H., and Stuiver, M. 1967. Late Pleistocene glacial stratigraphy and chronology, northeastern St. Elias Mountains, Yukon Territory, Canada. Geological Society of America. Bulletin, Vol. 78, No. 4, p. 485-510.

Meier, M. F., and Post, A. S. I969. What are glacier surges? Canadian Journal of Earth Sciences, Vol. 6, No. 4, Pt. 2, p. $807-17$.

Østrem, G. I959. Ice melting under a thin layer of moraine and the existence of ice cores in moraine ridges. Geografiska Annaler, Vol. 41, No. 4, p. 228-30.

Østrem, G. 1962. Ice-cored moraines in the Kebnekajse area, Sweden. Biuletyn Peryglacjalny, Nr. I I, p. 27 I-78.

Østrem, G. I 964 . Ice-cored moraines in Scandinavia. Geografiska Annaler, Vol. 46, No. 3, p. $282-337$.

Porter, S. C., and Denton, G. H. 1967. Chronology of neo-glaciation in the North American Cordillera. American fournal of Science, Vol. 265, No. 3, p. $177-210$.

Rutter, N. W. r 969 . Comparison of moraines formed by surging and normal glaciers. Canadian Journal of Earth Sciences, Vol. 6, No. 4, Pt. 2, p. 991-99. 